ISSN 2089-8673

Jurnal Nasional Pendidikan Teknik Informatika (JANAPATI)

Volume 1, Nomor 3, Desember 2012

\title{
PENGEMBANGAN ROBOT \\ PENULIS KARAKTER AKSARA BALI \\ BERBASIS NXT-G DENGAN LEGO MINDSTORM NXT
}

\author{
Oleh \\ I Gusti Ngurah Putra Arimbawa, Made Windu Antara Kesiman, S.T., M.Sc, I \\ Gede Mahendra Darmawiguna, S.Kom., M.Sc \\ Jurusan Pendidikan Teknik Informatika, Fakultas Teknik dan Kejuruan, Universitas \\ Pendidikan Ganesha (Undiksha) \\ Email : r4hgus@yahoo.co.id
}

\begin{abstract}
ABSTRAK
Robot adalah salah satu teknologi yang diciptakan untuk membantu meringankan pekerjaan manusia yang tersusun dari beberapa rangkaian elektronik dan juga mekanik. Salah satu penerapan robot dalam pendidikan yang menarik untuk dikembangkan adalah robot menulis untuk membentuk sebuah karakter aksara bali. Aksara Bali merupakan jenis tulisan yang biasanya digunakan oleh masyarakat Bali dalam menuliskan ajaranajaran Agama, geguritan, sajak dan karya sastra berbahasa Bali lainnya. Saat ini minat siswa dan kalangan umum untuk belajar aksara Bali sangat rendah. Perlu adanya sebuah motivator atau pengembangan agar masayarakat Bali kembali tertarik untuk belajar aksara Bali.

Perancangan perangkat lunak yang digunakan dalam penelitian ini adalah Use Case Diagram dan Activity diagram. Lingkungan implementasi perangkat lunak pengendali robot (Penyarikan Bot) ini berbasis Microsoft Visual C\# 2010 dan perangkat keras yang dipergunakan yaitu Lego Mindstrom NXT.

Beberapa testing telah dilakukan untuk menguji kelayakan system ini, antara lain : (1) Pengujian fungsional (black box testing), (2) pengujian konseptual (white box testing), (3) pengujian perangkat keras (hardware testing). Berdasarkan hal tersebut, robot sudah bisa melakukan penulisan Aksara Bali sesuai dengan yang direncanakan.
\end{abstract}

Kata Kunci : Robot, Aksara Bali, Lego Mindstrom NXT 
ISSN 2089-8673

Jurnal Nasional Pendidikan Teknik Informatika (JANAPATI)

Volume 1, Nomor 3, Desember 2012

\title{
THE DEVELOPMENT OF BALINESE SCRIPT WRITER ROBOT BASED NXT-G WITH LEGO MINDSTORM NXT
}

\author{
By \\ I Gusti Ngurah Putra Arimbawa \\ Jurusan Pendidikan Teknik Informatika, Fakultas Teknik dan Kejuruan, Universitas \\ Pendidikan Ganesha (Undiksha) \\ Email :r4hgus@yahoo.co.id
}

\begin{abstract}
Robot is one of technologies which was created for helping human being in their works that is composed of several electronic circuits and mechanic. One of applications of robot in education that is interesting to be developed is writer robot for creating a character in Balinese script. Balinese script is a kind of scripts that is usually used by Balinese in writing religion precept, geguritan, poem and another Balinese literature. However, nowadays the interest of students and common people in studying the Balinese script is very low. It needs a motivator or development plan to make Balinese interest in learning Balinese script again.

Design of software that is used in this research is Use Case Diagram and Activity Diagram. The scope of implementation for this controlling robot software is created by Microsoft Visual C\# 2010 developing software and also use Lego Mindstrom NXT as the hardware.

Several testing have been done for examining the expedience system such as (1) functional testing (black box testing), (2) conceptual testing (white box testing), (3) Hardware testing. Those testing indicate that robot is able to write Balinese script based on the planning properly.
\end{abstract}

Keyword : Robot, Aksara Bali, Lego Mindstrom NXT 
ISSN 2089-8673

Jurnal Nasional Pendidikan Teknik Informatika (JANAPATI)

Volume 1, Nomor 3, Desember 2012

\section{PENDAHULUAN}

Robotika adalah salah satu teknologi yang diciptakan untuk membantu meringankan pekerjaan manusia yang tersusun dari beberapa rangkaian elektronik dan juga mekanik. robot adalah suatu alat yang pada batasan-batasan tertentu dapat bekerja secara otomatis sesuai dengan perintah dari perancang (Yudantara, 2010). Salah satu penerapan robotika adalah di bidang pendidikan. Pendidikan (edukasi) merupakan sebuah proses interaktif, antara siswa dengan siswa, siswa dengan guru, dan siswa dengan dunia nyata. Proses pembelajaran akan lebih menarik dan berarti jika lebih banyak tool (alat batu) yang mampu mendukung proses interaktif tersebut. Robot dapat mengajarkan kepada siswa bagaimana menggunakan teori dan pengetahuan yang diperolehnya di kelas untuk aplikasi nyata/terapan. Salah satu penerapan robot dalam pendidikan yang menarik untuk dikembangkan adalah robot menulis. Pembelajaran menulis dengan menggunakan robot menulis diharapkan mampu meng-inspirasi siswa dan memberi keyakinan yang mantap bahwa apa yang mereka pelajari di sekolah, memang bermanfaat bagi kehidupan mereka. Robot Menulis memerlukan sistem mekanika yang memiliki keakuratan tinggi, karena dalam robot menulis ini diperlukan beberapa motor yang saling bekerja sama untuk membentuk sebuah karakter. Namun, saat ini minat siswa dan kalangan umum untuk belajar aksara Bali sangat rendah. Perlu adanya sebuah motivator atau pengembangan agar masayarakat Bali kembali tertarik untuk belajar aksara Bali.

Berdasarkan uraian di atas, pada skripsi ini peneliti tertarik untuk mengembangkan "Robot Penulis Karakter Aksara Bali Berbasis NXT-G Dengan Lego Mindstorm NXT". Penulis ingin mengembangkan lebih jauh robot tersebut, dengan menggunakan perpaduan konsep antara mobile robot dan arm robot sehingga robot dapat menulis tulisan aksara Bali pada kertas. Dari latar belakang di atas dapat dirumuskan beberapa permasalahan yang akan dibahas sebagai berikut, Bagaimana merancang dan mengimplementasikan rangkaian mekanik robot penulis karakter aksara Bali 
ISSN 2089-8673

Jurnal Nasional Pendidikan Teknik Informatika (JANAPATI)

Volume 1, Nomor 3, Desember 2012

menggunakan Lego Mindstorm NXT. Adapun tujuan yang ingin dicapai dalam penelitian skripsi ini adalah Merancang dan mengimplementasikan rangkaian mekanik robot penulis karakter aksara Bali menggunakan Lego Mindstorm NXT.

\section{Metodemologi}

\subsection{Robot Menulis}

Robot menulis memiliki ciri khas yaitu menggunakan alat tulis (pena, pensil, atau spidol) yang digunakan untuk menulis karakter atau angka di sebuah kertas. Robot ini pada umumnya menggunakan beberapa motor sebagai penggerak alat tulis maupun landasannya.

\subsection{Lego Mindstorm NXT}

Lego Mindstorm NXT adalah perangkat robot edukasional keluaran Lego. Seri NXT ini resmi dirilis pada tahun 2006, sebagai penerus dari seri sebelumnya, yaitu RIS (Robotics Invention System), yang sudah sukses di pasaran. Dengan menggunakan Mindstorm, membuat robot menjadi relatif mudah, dibandingkan dengan menyolder sirkuit atau memasang motor sendiri. Lego Mindstorm NXT tersedia dalam 2 versi, yaitu Educational Base Set dan Retail Set. Education Base Set ditujukan untuk kalangan pendidikan dengan fokus pada pembelajaran, sementara Retail Set lebih ditujukan pada penggemar robot. Di dalam Educational Base Set, paket yang tersedia sudah merupakan suatu kesatuan utuh yang tidak bisa dipisahkan ketika membeli. Namun, untuk Retail Set diperbolehkan untuk membeli bagian tertentu saja.

Lego Mindstorm NXT dapat diprogram dengan berbagai bahasa pemrograman seperti C dan Java setelah terlebih dahulu mengganti firmware Lego dengan firmware yang sesuai dengan bahasa pemrograman yang akan digunakan. Firmware merupakan perangkat lunak yang secara permanen tertanam di dalam perangkat keras yang dapat digunakan sebagai pengganti. Firmware dalam Lego Mindstorm NXT antara lain leJOS NXJ, Robot C, BrickOS dan berbagai firmware lainnya. Untuk membuat program di Mindstorm NXT, tersedia banyak pilihan. Lego sendiri sudah menyediakan tool NXT-G. Microsoft menyediakan Microsoft Robotics Studio yang cocok untuk aplikasi yang 
relatif kompleks sebab pemrosesan data dilakukan di komputer. Dan masih banyak tool lain dari pihak ketiga, seperti NBC, NXC, BrixCC, leJOS, dan pyNXT.

\subsection{Displaying Segment}

Displaying Segment merupakan segment-segment yang digunakan sebagai standar penampilan karakter yang terdiri dari seven displaying segment, Sixteen displaying segment, dot matrix.

\subsubsection{Seven Displaying Segment}

Seven-segment display (SSD)) adalah salah satu perangkat layar untuk menampilkan sistem angka desimal yang merupakan alternatif dari layar dot matrix. Layar tujuh segmen ini seringkali digunakan pada jam digital, meteran elektronik, dan perangkat elektronik lainnya yang menampiklan informasi numerik. Ide mengenai layar tujuh segmen ini sudah cukup tua. Pada tahun 1910 misalnya, sudah ada layar tujuh segmen yang diterangi oleh lampu pijar yang digunakan pada panel sinyal kamar ketel suatu pembangkit listrik.

\subsubsection{Sixteen Displaying Segment}

Sixteen segment seperti namanya terdiri dari 16 buah Segmen LED + 1 Dot dan disusun sedemikian rupa sehingga menjadi Display sixteen segment yang dapat menampilkan angka, huruf dan simbol-simbol tertentu. Segmen ini merupakan perkembangan dari seven segment dan fourteen segment. Dot dapat ditampilkan sebagai segmen tambahan. Dot, biasanya terbentuk dengan mengkombinasikan titik desimal dengan segmen berbentuk busur yang letaknya berdekatan. Dengan begini titik atau koma ini dapat menggantikan pekerjaan segmen vertikal tengah sebagai titik dan segmen diagonal kiri bawah sebagai koma. Segmen seperti ini sangat umum digunakan pada mesin pinball untuk menampilkan skor dan informasi lainnya. Sebagai contoh bila segmen B dan C menyala maka dihasilkan angka desimal 1, bila segmen A2, B, dan C 
menyala maka muncul angka desimal 7 dan sebagainya. Sixteen segment ini dapat membentuk angka, huruf, ataupun simbol-simbol lainnya.

\subsubsection{Dot Matrix ‘}

Dot Matrix merupakan tekstur array 2 dimensi, yang diggunakan untuk merepresentasikan sebuah karakter, simbol, ataupun gambar. Setiap alat canggih saat ini menggunakan dot matrix untuk menampilkan informasi, seperti telepon selular, reklame bergerak, printer.

\subsection{Aksara Bali}

Aksara Bali adalah aksara tradisional masyarakat Bali dan berkembang di Bali. Biasanya digunakan untuk penulisan aksara Bali berjumlah 47 karakter, 14 di antaranya merupakan huruf vokal (aksara suara). Huruf konsonan (aksara wianjana) berjumlah 33 karakter. Aksara wianjana Bali yang biasa digunakan berjumlah 18 karakter. Juga terdapat aksara wianjana Kawi yang digunakan pada kata-kata tertentu, terutama katakata yang dipengaruhi bahasa Kawi dan Sanskerta.

\subsection{Pixelization}

Pixelization merupakan langkah mengubahan citra digital dari citra asli ke citra yang beresolusi rendah. Hal ini dilakukan untuk mendapatkan titik - titik utama yang menyusun suatu citra. Mendapatkan hasil pixelization dari citra aksara Bali bertujuan untuk menentukan titik - titik utama pada aksara Bali untuk nanti dibuatkan garis yang dipergunakan untuk menuliskan aksara Bali oleh robot. Pensil yang digerakkan oleh robot akan berjalan mengikuti titik-titik setiap Aksara. Sehingga menciptakan sebuah karakter aksara Bali.

\subsection{Perancangan}

Perangkat lunak yang akan dibangun mampu mengimplementasikan pengendalian robot melalui Bluetooth dan pergerakan robot untuk menulis karakter. Perangkat lunak yang akan dibangun bernama Penyarikan Bot. Perangkat keras yang dibangun mampu mengimplementasikan rangkaian mekanik robot untuk menulis karakter. 
Perangkat keras Robot Penulis Karakter merupakan perangkat keras yang dikendalikan dari jarak tertentu oleh perangkat lunak sistem pengendali robot. Perangkat keras robot yang dibangun diharapkan dapat membantu dalam efesiensi penulisan karakter sehingga robot memungkinkan untuk menulis karakter pada kertas yang lebih besar dari kertas A4. Perangkat keras ini juga diharapkan mampu mengimplemetasikan perpaduan konsep antara robot mobile dengan robot penulis.

\subsection{Algoritma Mekanika Penulisan}

NXT-G atau LEGO MINDSTORM Education NXT adalah software untuk memprogram NXT Brick dari komputer. NXT-G dibangun dengan engine LabVIEW ${ }^{\mathrm{TM}}$ dari National Instruments dan bekerja dengan NXT Brick. Pemrograman dapat dilakukan secara grafikal dengan mengambil ikon-ikon yang sudah tersedia lalu merangkainya secara algoritmis sehinga robot dapat bergerak secara sesuai. File extention yang dihasilkan oleh program ini adalah .rbt, dan yang sudah dicompilasi oleh robot adalah .rxe. Gambar 2.1 merupakan contoh Software NXT-G.

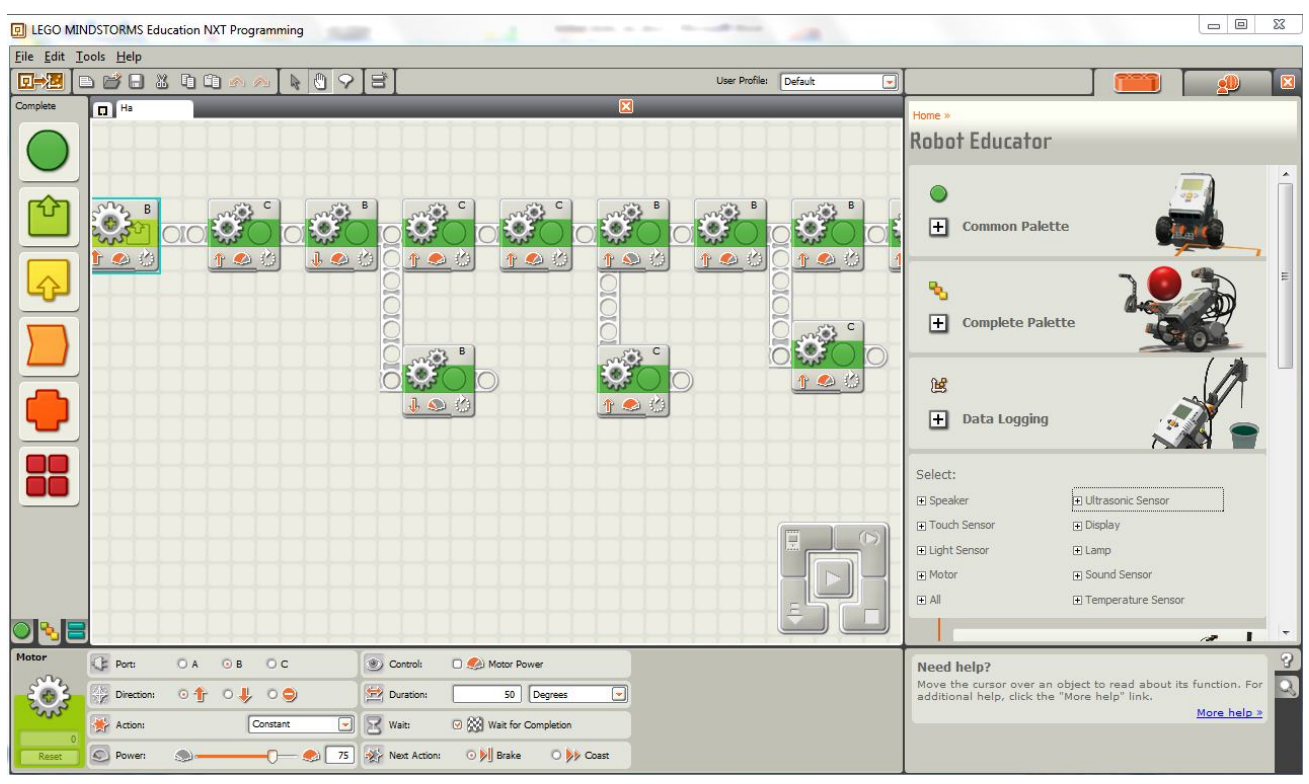

Gambar 2.1 Software NXT-G

Dengan bantuan software tersebut penulis mengimplementasikan algoritma mekanika penulisan robot. Algoritma ditulis pada rangkaian block-block 
Sintaks yang tersedia pada NXT-G. Berikut contoh salah satu rangkaian block aksara Ha.rxe.

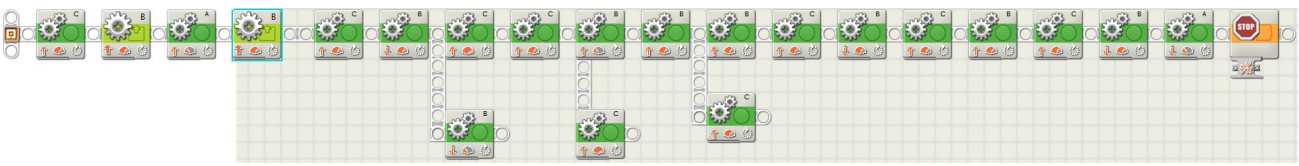

Gambar 2.2 Rangkaian Block dari aksara Ha.rxe

\subsection{Use Case Diagram}

Use Case Diagram dari perangkat lunak yang akan dibuat ditunjukkan oleh Gambar 2.1. Pada gambar tersebut dapat dilihat bahwa terdapat dua actor yaitu user dan robot. User dapat mengunakan sistem melalui dua proses yaitu koneksi Bluetooth dan pengiriman Pesan. Sedangkan robot berhubungan dengan proses Pengiriman File dan penulisan karakter
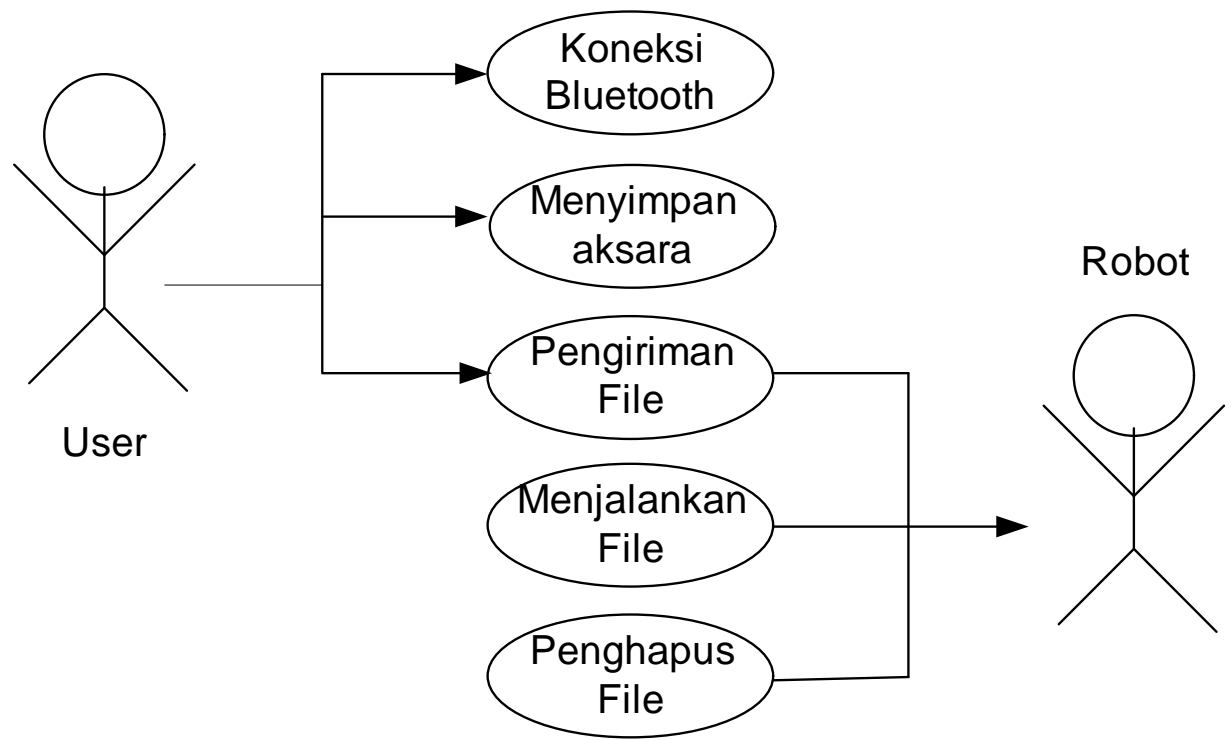

Gambar 2.1 Use Case Diagram Perangkat Lunak Sistem Pengendali Robot

\subsection{Activity Diagram}

\subsubsection{Activity Diagram Proses Koneksi Bluetooth}

Proses pada use case diagram seperti yang ditunjukkan oleh Gambar 2.1, dapat diuraikan menjadi activity diagram dari proses koneksi Bluetooth sebagaimana ditunjukkan oleh Gambar 2.2 berikut ini. 
ISSN 2089-8673

Jurnal Nasional Pendidikan Teknik Informatika (JANAPATI)

Volume 1, Nomor 3, Desember 2012

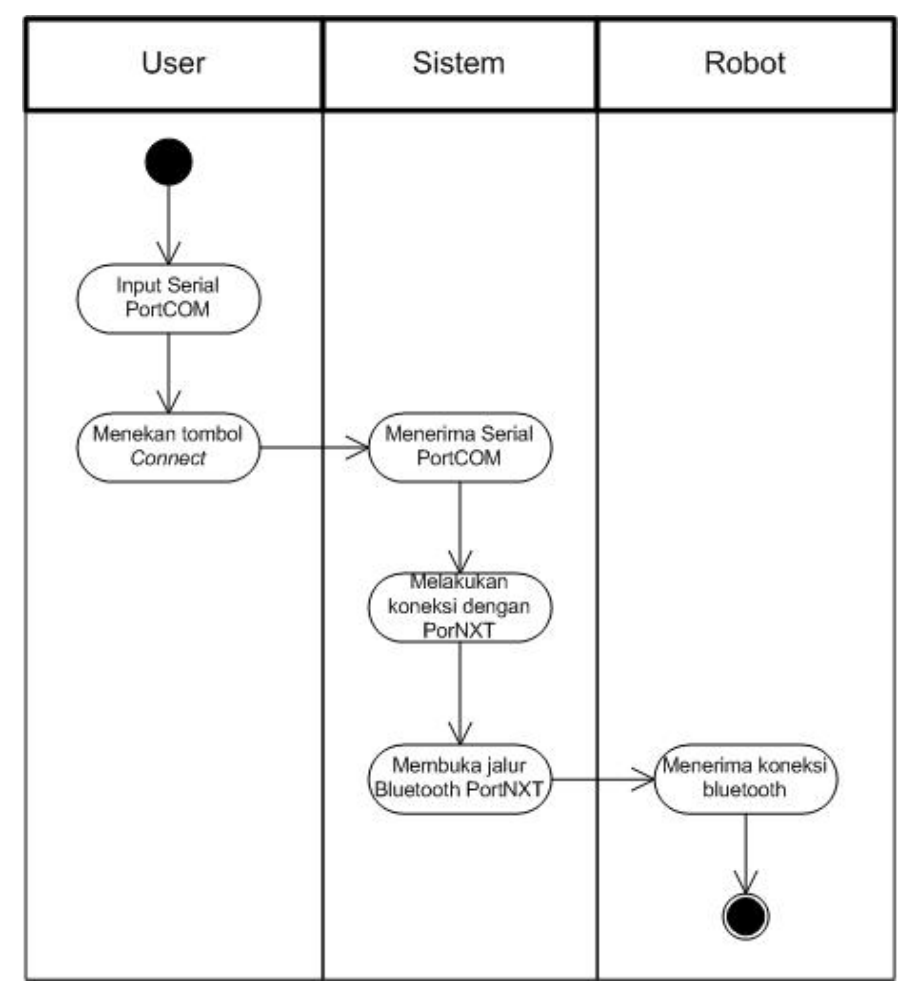

Gambar 2.1 Activity Diagram Proses Koneksi Bluetooth

\subsubsection{Activity Diagram Proses Penyimpanan aksara}

Proses pada use case diagram seperti yang ditunjukkan oleh Gambar 2.1, dapat diuraikan menjadi activity diagram dari proses pengiriman file program sebagaimana ditunjukkan oleh Gambar 2.3 berikut ini. 


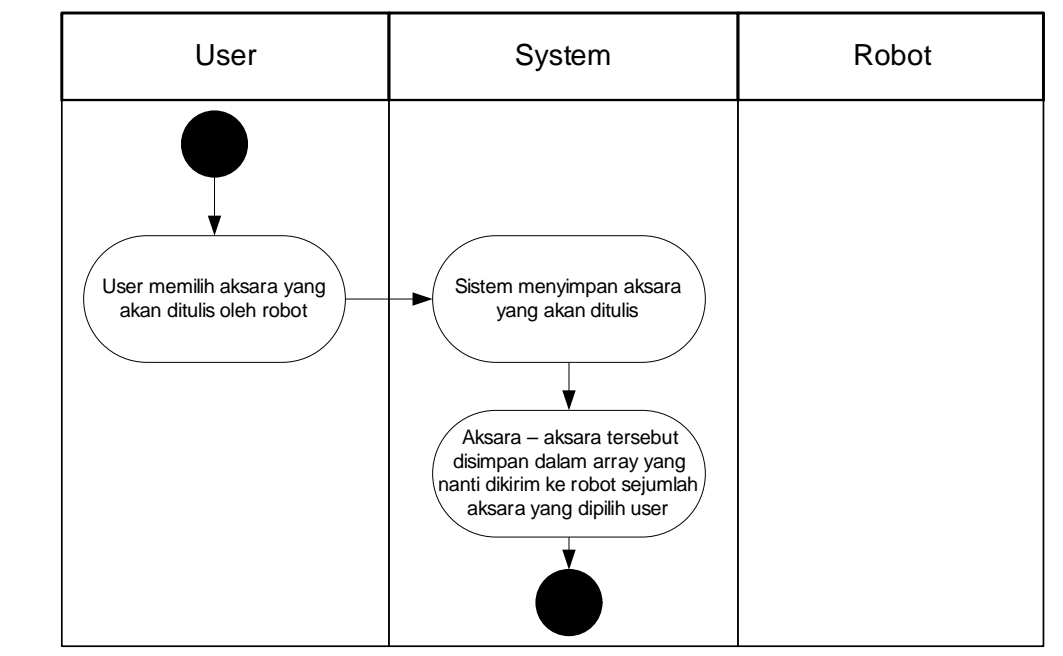

Gambar 2.2 Activity Diagram Proses Penyimpanan Aksara

\subsubsection{Activity Diagram Proses Pengiriman File}

Proses pada use case diagram seperti yang ditunjukkan oleh Gambar 2.1, dapat diuraikan menjadi activity diagram dari proses Pengiriman File sebagaimana ditunjukkan oleh Gambar 2.4 berikut ini.

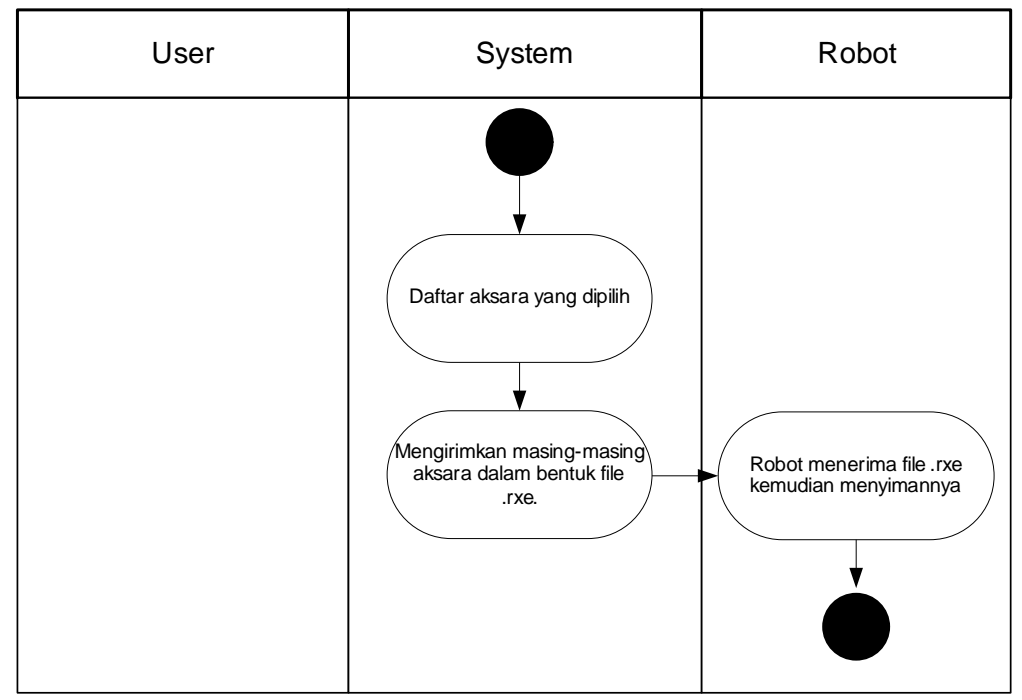

Gambar 2.3 Activity Diagram Proses Penerimaan File 


\subsubsection{Activity Diagram Proses Penulisan Karakter}

Proses pada use case diagram seperti yang ditunjukkan oleh Gambar 3.1, dapat diuraikan menjadi activity diagram dari proses penulisan karakter sebagaimana ditunjukkan oleh Gambar 3.5 berikut ini.

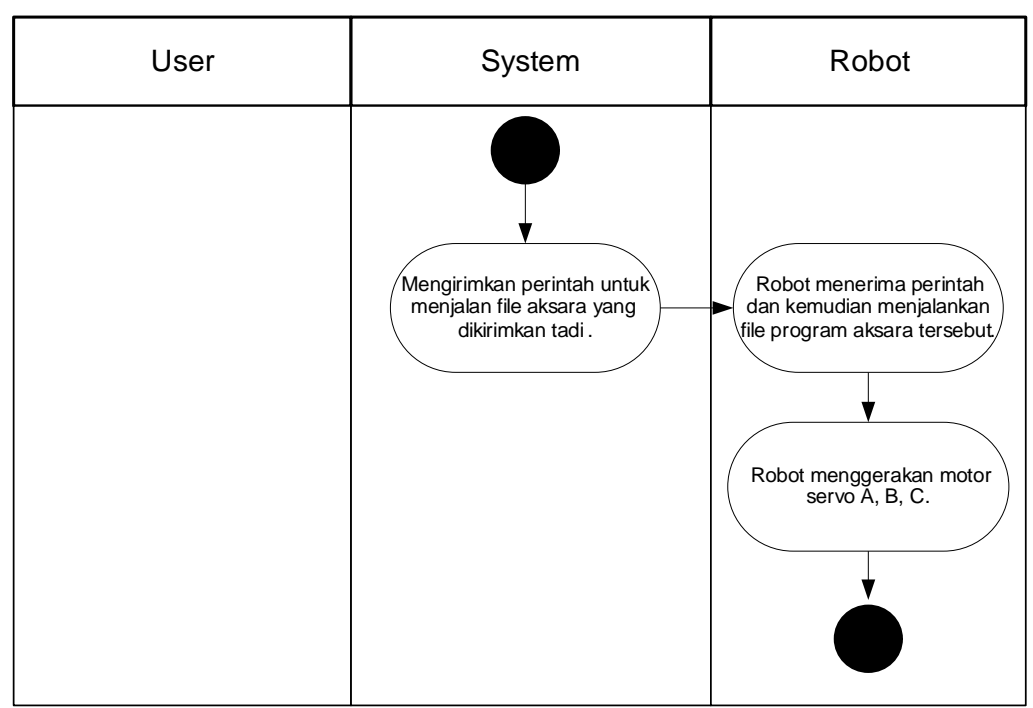

Gambar 3.4 Activity Diagram Proses Penulisan Karakter

\subsubsection{Activity Diagram Proses Penghapusan File}

Proses pada use case diagram seperti yang ditunjukkan oleh Gambar 3.1, dapat diuraikan menjadi activity diagram dari proses Penghapusan file .rxe sebagaimana ditunjukkan oleh Gambar 3.6 berikut ini.

\begin{tabular}{|l|l|l|}
\hline User & System & Robot \\
\hline & & Mengirimkan perintah untuk \\
Menghapus file aksara
\end{tabular}


Gambar 3.5 Activity Diagram Proses Penghapusan File

\subsection{Rancangan Antarmuka}

Perancangan antar muka perangkat lunak adalah rancangan dan susunan itemitem yang akan dibentuk menjadi antar muka pengguna perangkat lunak. Perancangan antar muka meliputi perancangan struktur menu dan perancangan antar muka.

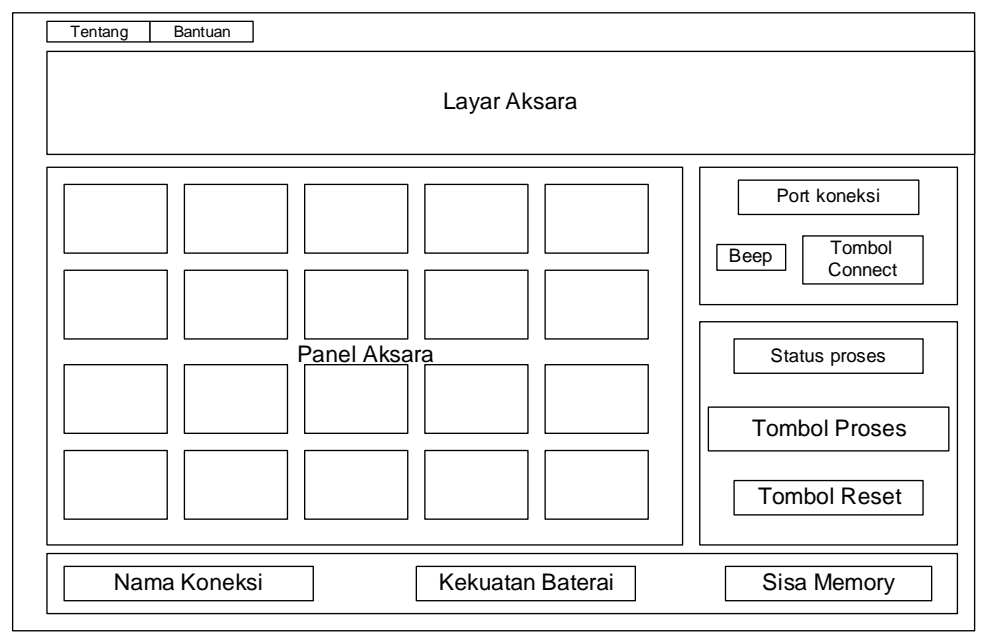

Gambar 2.3 Form Utama Penyarikan Bot

\subsection{Perancangan Mekanik Perangkat Keras}

Rancangan mekanik perangkat keras adalah rancangan dan susunan komponenkomponen dari Lego Mindstorm NXT yang akan dirakit menjadi rangkaian mekanik perangkat keras robot penulis karakter. Perangkat keras yang akan dibangun menggunakan 3 servo motor dan sebuah NXT Brick, dimana perangkat keras akan berupa robot mobile. Rancangan mekanik perangkat keras Robot Penulis Karakter dapat dilihat pada Gambar 2.4 berikut ini.

Motor 2

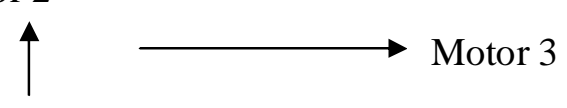




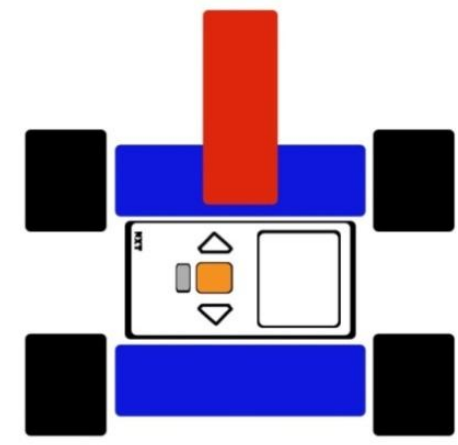

Gambar 2.4 Rancangan Perangkat Keras Robot

\section{Pembahasan}

\subsection{Implementasi Form Utama Aplikasi Peyarikan Bot}

Hasil implementasi dari perancangan layar antar muka perangkat lunak berupa tampilan visual untuk user interface sesuai dengan lingkungan implementasi perangkat lunak. Rancangan layar antar muka perangkat lunak pengendali robot diimplementasikan menggunakan control-control yang terdapat pada Microsoft Visual Studio 2010 Ultimate. Adapun layar antar muka yang telah diimplementasikan adalah sebagai berikut ini.

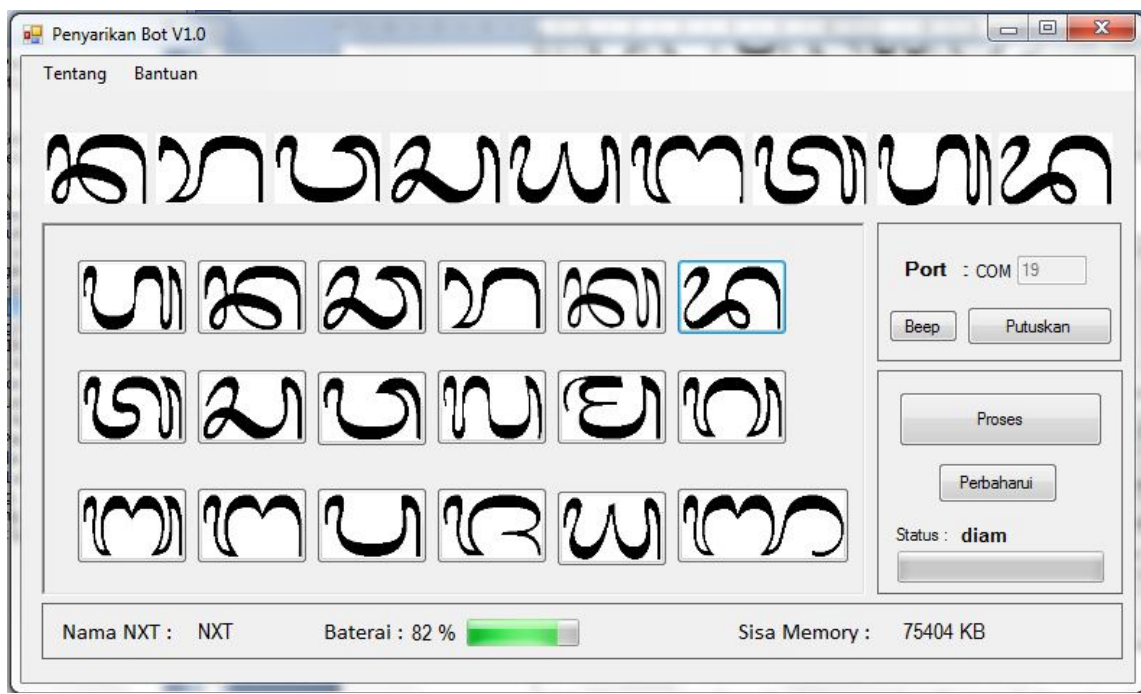

Gambar 3.1 Implementasi Form Utama Aplikasi Peyarikan Bot sesudah terkoneksi 


\subsection{Implementasi Mekanik Perangkat Keras}

Hasil implementasi dari perancangan mekanik perangkat keras menggunakan perangkat Lego Mindstorm education set 9797 dan set 9648. Karena keterbatasan motor, sehingga pergerakan maju dan mundur oleh 4 roda dipusatkan pada motor A (belakang). Motor B (depan bawah) berfungsi untuk pergerakan alat tulis ke kiri dan ke kanan. Sedangkan untuk motor C (depan atas) digunakan untuk pergerakan alat tulis ke atas dan ke bawah. Rangkaian mekanik yang telah diimplementasikan seperti Gambar 3.2 berikut.

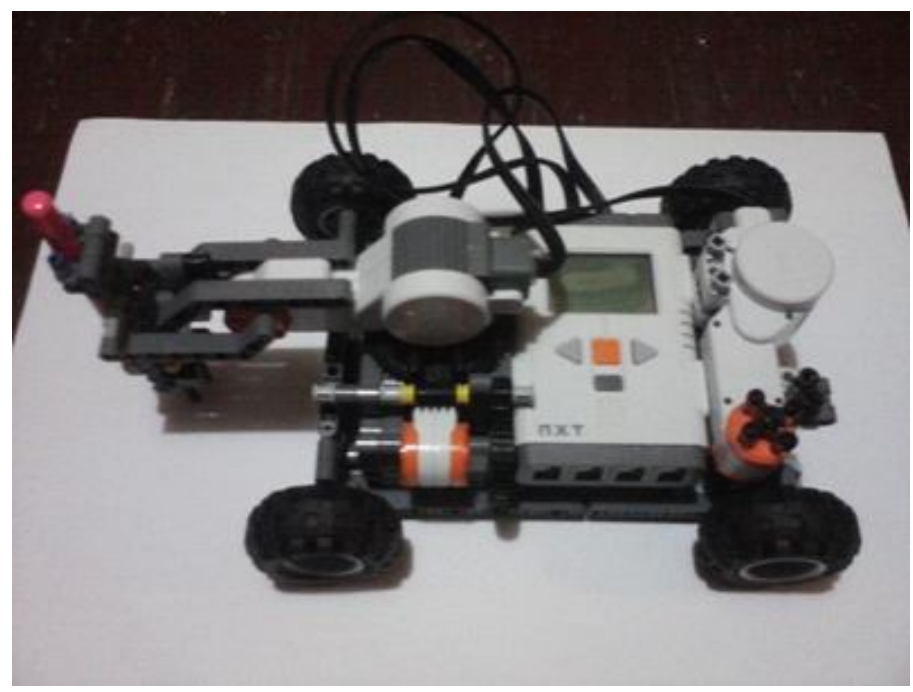

Gambar 3.2 Implementasi Mekanik Perangkat Keras Robot Penulis Karakter

\subsection{Pengujian Tingkat Keakuratan Hasil Penulisan Karakter Aksara}

Untuk tingkat keakuratan hasil penilisan karakter dapat dilihat pada Tabel 3.3 Tabel 3.1 Tingkat Keakuratan Hasil Penulisan Karakter

\begin{tabular}{|c|c|c|c|c|c|}
\hline No & $\begin{array}{l}\text { Nama } \\
\text { Aksara }\end{array}$ & AksaraAsli & $\begin{array}{l}\text { Aksara hasil } \\
\text { Pixelization }\end{array}$ & Aksara hasil & Kualifikasi \\
\hline 1 & $\mathrm{Ha}$ & & & & Sangat Tepat \\
\hline 2 & $\mathrm{Na}$ & & & & Sangat Tepat \\
\hline 3 & $\mathrm{Ca}$ & & & & Sangat Tepat \\
\hline
\end{tabular}




\begin{tabular}{|l|l|l|l|}
\hline No & Nama \\
Aksara
\end{tabular}


Secara umum hasil pengujian fungsional menunjukkan bahwa sistem sudah bisa menangani data masukan dan menampilkan output yang sesuai dengan apa yang direncanakan. Hasil pengujian konseptual menunjukkan bahwa sistem telah melaksanakan mekanisme algortima sesuai dengan yang direncanakan.

\subsection{Pengujian Perangkat Keras}

Pengujian perangkat keras bertujuan untuk mengevaluasi pemenuhan robot atau komponen dengan kebutuhan proses tertentu. Pengujian ini dilakukan untuk mekanik perangkat keras, dilakukan untuk memperlihatkan bahwa rangkaian mekanik bekerja dengan baik dalam arti pergerakan yang dilakukan benar-benar sesuai dengan input yang diterima. Dari pergerakan yang dihasilkan, kemampuan mekanik robot dalam memenuhi kebutuhan pemakai dapat diukur sekaligus dapat diketahui kesalahankesalahannya.

Tabel 3.2 Pelaksanaan Uji Kasus Perangkat Keras

\begin{tabular}{|l|l|l|l|l|}
\hline No & Uji Coba & $\begin{array}{l}\text { Komponen } \\
\text { Robot }\end{array}$ & Penanganan & Pelaksanaan \\
\hline 1 & $\begin{array}{l}\text { Bergerak maju } \\
\text { dan mundur }\end{array}$ & Motor A & $\begin{array}{l}\text { Motor A bergerak } \\
\text { maju atau mundur }\end{array}$ & $\sqrt{ }$ \\
\hline 2 & $\begin{array}{l}\text { Bergerak ke kiri } \\
\text { dan ke kanan }\end{array}$ & Motor B & $\begin{array}{l}\text { Motor B bergerak ke } \\
\text { kiri dan ke kanan }\end{array}$ & $\sqrt{ }$ \\
\hline 3 & $\begin{array}{l}\text { Bergerak ke atas } \\
\text { dan ke bawah }\end{array}$ & Motor C & $\begin{array}{l}\text { Motor C bergerak ke } \\
\text { atas dan ke bawah }\end{array}$ & $\sqrt{ }$ \\
\hline
\end{tabular}

Secara umum hasil pengujian perangkat keras menunjukkan bahwa robot sudah bisa melakukan pergerakan sesuai dengan apa yang direncanakan. Namun dalam penelitian ini menemukan hambatan pada rangkaian mekanik yang dihasilkan, yaitu masalah pergerakan motor B. Pada rangkaian mekanik motor B menggunakan perpaduan beberapa gear yang dapat menimbulkan peningkatan gaya gesek ketika bagian pemegang alat tulis bergerak ke kanan. Selain itu banyaknya perintah penulisan karakter yang diterima mempengaruhi kecepatan motor B. Pergerakan motor akan lebih lambat ke arah kanan ketika melakukan proses penulisan karakter secara berturut-turut. 
ISSN 2089-8673

Jurnal Nasional Pendidikan Teknik Informatika (JANAPATI)

Volume 1, Nomor 3, Desember 2012

\section{Penutup}

\subsection{Simpulan}

Berdasarkan penelitian yang telah dilakukan yaitu "Pengembangan Robot Penulis Karakter Aksara Bali Berbasis NXT-G Menggunakan Lego Mindstorm NXT" adapun simpulan yang didapat antara lain.

a. Rancangan fungsional sistem pengendali robot penulis karakter Aksara pada penelitian ini digambarkan oleh use case diagram dan activity diagram. Pada use case diagram terdapat 5 proses yaitu : proses melakukan koneksi Bluetooth, proses penyimpanan aksara, proses pengiriman file, proses menulis karakter, dan proses penghapusan file. Rancangan form perangkat lunak dan mekanik perangkat keras dibuat dalam bentuk gambar sederhana yang menyerupai tampilan dari form dan mekanik yang akan dibuat.

b. Pada tahap implementasi sistem pengendali robot penulis karakter menghasilkan suatu program aplikasi yang menangani proses melakukan koneksi Bluetooth, proses mengirim pesan, proses meneriman pesan, dan proses menulis karakter. Sedangkan implementasi perangkat keras menghasilkan sebuah robot yang dapat melakukan pergerakan robot ke depan dan ke belakang, pergerakan alat tulis ke kiri dan ke kanan, serta ke atas dan ke bawah dalam menulis karakter.

c. Pengembangan Robot Penulisan Karakter Aksara Bali ini memiliki kedala dalam proses penulisan aksara dimana karakater yang dihasilkan sangat tergantung terhadap kekuatan baterai dan koefisien gesek antar gear -gear robot.

\subsection{Saran}

Berdasarkan penelitian yang telah dilakukan yaitu "Pengembangan Robot Penulisan Karakter Berbasis NXT-G Menggunakan Lego Mindstorm NXT" adapun saran yang didapat antara lain.

a. Dalam pengembangan selanjutnya, Pengembang hendaknya selalu memperhatikan level kekuatan baterai karena hasil penulisan karakter yang sangat dipengaruhi oleh level baterai pada NXT Brick. 
ISSN 2089-8673

Jurnal Nasional Pendidikan Teknik Informatika (JANAPATI)

Volume 1, Nomor 3, Desember 2012

b. Dalam pengembangan selanjutnya, penulisan karakter aksara tak terbatas hanya pada aksara dasar saja sehingga dapat menuliskan kalimat atau frasa dalam Bahasa Bali.

c. Dalam pengembangan selanjutnya, sebaiknya rancangan mekanik robot penulis karakter pada komponen pemegang alat tulis dirangkai menggunakan perpaduan beberapa gear yang lebih sesuai sehingga dapat mengurangi gaya gesek yang menimbulkan perlambatan pada gerakan motor.

\section{Daftar Pustaka}

Crisnapati, Padma Nyoman. 2009. "Mengendalikan Lego NXT Robo Laptop Secara Remote Via Bluetooth Dan Wifi Berbasis Webcam". Tugas Akhir. Jurusan Teknik Informatika, Institut Teknologi Sepuluh Nopember Surabaya

Devi Novayanti. 2012. "Pengembangan Robot Penulis Karakter Berbasis NXT-G Dengan Lego Mindstorm NXT", Universitas Pendidikan Ganesha. Singaraja

Widodo Budiharto.2010."Robotika teori + implementasi”. Penerbit Andi. Yogyakarta

Deitel, H.M. et.al. 2002. C\# How To Program. New Jersey : Prentice-Hall

Anthony. 2004. "Stock Ticker Tape with 16 segment display".

http://www.deepwaveenergy.com/personal_page/stockticker (Diakses tanggal 19 Pebruari 2012)

Garjo, Cah. 2010. "Bluetooth, Logo dan Sejarahnya". http://garjo.mywapblog.com/bluetooh-logo-dan-sejarahnya (Diakses tanggal 24 Pebruari 2012).

Igos Center Bandung. 2009. "Lego Mindstorm NXT". http://saung.igoscenter.org/LEGO_Mindstorm_NXT (Diakses tanggal 24 Pebruari 2012).

ITC Kosambi F2. 2008. "Lego Mindstorms NXT : Education vs Retail". http://nextsys.web.id/edukasi/lego-mindstorms-nxt-indonesia/legomindstorms-nxt-education-base-vs-retail (Diakses tanggal 26 Pebruari 2012). 
ISSN 2089-8673

Jurnal Nasional Pendidikan Teknik Informatika (JANAPATI)

Volume 1, Nomor 3, Desember 2012

The LEGO Group, 2006. "LEGO MINDSTORM NXT Bluetooth Developer Kit”.

http://cache.lego.com/upload/contentTemplating/Mindstorms

Overview/otherfiles/2057/LEGO\%20MINDSTORMS\%20NXT\%20Bluetoot

h\%20Developer\%20Kit_58CE458E-5292-4CB0-93D2-4BEC821C13C2.zip

(Diakses tanggal 28 Pebruari 2012).

Yayasan Bali Galang. 2003." Development of Character Encoding, Smart Font, and Keyboard Driver for the Balinese Script" tersedia pada http://www.babadBali.com/aksaraBali/proposal-eng.htm (diakses pada tanggal 28 Pebruari 2012)

RobotC.net Forum 2009. "Transfer Files PC to NXT" tersedia pada http://www.robotc.net/forums/viewtopic.php?t=604 (diakses tanggal 16 Juni 2012) 